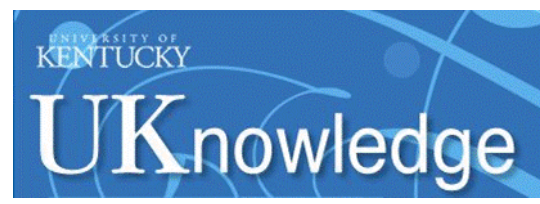

University of Kentucky

UKnowledge

\title{
Development of one-step TaqMan® real-time reverse transcription-PCR and conventional reverse transcription-PCR assays for the detection of equine rhinitis $A$ and $B$ viruses
}

\author{
Zhengchun Lu \\ University of Kentucky, zlu2@uky.edu \\ Peter J. Timoney \\ University of Kentucky, ptimoney@email.uky.edu \\ Jena White \\ University of Kentucky, jenale@gmail.com \\ Udeni B R Balasuriya \\ University of Kentucky, ubalasuriya@uky.edu
}

Follow this and additional works at: https://uknowledge.uky.edu/gluck_facpub

Part of the Veterinary Medicine Commons

Right click to open a feedback form in a new tab to let us know how this document benefits you.

\section{Repository Citation}

Lu, Zhengchun; Timoney, Peter J.; White, Jena; and Balasuriya, Udeni B R, "Development of one-step TaqMan ${ }^{\circledR}$ real-time reverse transcription-PCR and conventional reverse transcription-PCR assays for the detection of equine rhinitis A and B viruses" (2012). Veterinary Science Faculty Publications. 9.

https://uknowledge.uky.edu/gluck_facpub/9

This Article is brought to you for free and open access by the Veterinary Science at UKnowledge. It has been accepted for inclusion in Veterinary Science Faculty Publications by an authorized administrator of UKnowledge. For more information, please contact UKnowledge@lsv.uky.edu. 


\section{Development of one-step TaqMan ${ }^{\circledR}$ real-time reverse transcription-PCR and conventional reverse transcription-PCR assays for the detection of equine rhinitis $A$ and $B$ viruses}

Digital Object Identifier (DOI)

http://dx.doi.org/10.1186/1746-6148-8-120

Notes/Citation Information

Published in BMC Veterinary Research, v. 8, 120.

(C) 2012 Lu et al.; licensee BioMed Central Ltd.

This is an Open Access article distributed under the terms of the Creative Commons Attribution License ( http://creativecommons.org/licenses/by/2.0), which permits unrestricted use, distribution, and reproduction in any medium, provided the original work is properly cited. 


\title{
Development of one-step TaqMan ${ }^{\circledR}$ real-time reverse transcription-PCR and conventional reverse transcription-PCR assays for the detection of equine rhinitis $A$ and $B$ viruses
}

\author{
Zhengchun Lu, Peter J Timoney, Jena White and Udeni B R Balasuriya*
}

\begin{abstract}
Background: Equine rhinitis viruses $A$ and $B$ (ERAV and ERBV) are common equine respiratory viruses belonging to the family Picornaviridae. Sero-surveillance studies have shown that these two viral infections are prevalent in many countries. Currently, the diagnosis of ERAV and ERBV infections in horses is mainly based on virus isolation (VI). However, the sensitivity of VI testing varies between laboratories due to inefficient viral growth in cell culture and lack of cytopathic effect. Therefore, the objective of this study was to develop molecular diagnostic assays (real-time RT-PCR [rRT-PCR] and conventional RT-PCR [CRT-PCR] assays) to detect and distinguish ERAV from ERBV without the inherent problems traditionally associated with laboratory diagnosis of these infections.

Results: Three rRT-PCR assays targeting the 5'-UTR of ERAV and ERBV were developed. One assay was specific for ERAV, with the two remaining assays specific for ERBV. Additionally, six CRT-PCR assays targeting the 5'-UTR and 3D polymerase regions of ERAV and ERBV were developed. Both rRT-PCR and CRT-PCR assays were evaluated using RNA extracted from 21 archived tissue culture fluid (TCF) samples previously confirmed to be positive for ERAV $(n=11)$ or ERBV $(n=10)$ with mono-specific rabbit antisera. The ERAV rRT-PCR and CRT-PCR assays could only detect ERAV isolates and not ERBV isolates. Similarly, the ERBV rRT-PCR and CRT-PCR assays could only detect ERBV isolates and not ERAV isolates. None of the rRT-PCR or CRT-PCR assays cross-reacted with any of the other common equine respiratory viruses. With the exception of one CRT-PCR assay, the detection limit of all of these assays was 1 plaque forming unit per $\mathrm{ml}$ (pfu/ml).
\end{abstract}

Conclusion: The newly developed rRT-PCR and CRT-PCR assays provide improved diagnostic capability for the detection and differentiation of ERAV and ERBV. However, a larger number of clinical specimens will need to be tested before each assay is adequately validated for the detection of ERAV and/or ERBV in suspect cases of either viral infection.

Keywords: Real-time RT-PCR, RT-PCR, Equine rhinitis virus A, Equine rhinitis virus B

\footnotetext{
*Correspondence: ubalasuriya@uky.edu

Maxwell H. Gluck Equine Research Center, Department of Veterinary Science, University of Kentucky, 108 Maxwell H, Lexington, KY 40546, USA
} 


\section{Background}

The family Picornaviridae is a large family of viruses classified into several genera with extensive diversity in physical properties, antigenicity and mechanisms of pathogenesis [1]. Although there are many different picornaviruses with various degrees of relatedness, all share several features in common. The picornaviruses have a single-stranded positive-sense RNA genome with a 5'-end covalently linked to a VPg (virion protein genome-linked) protein. The RNA genome contains a 5' untranslated region (UTR) with an internal ribosome entry site (IRES), a single open reading frame (ORF) encoding the viral capsid proteins and the viral replicase proteins, a 3' UTR and a 3' poly(A) tail [2]. The ORF is divided into three regions: $\mathrm{P} 1$ encodes four structural proteins (VP1-VP4); P2 (2A, 2B, 2C and 2B3) and P3 (3A, 3B, 3B2, 3C and 3D) encode nine non-structural proteins [3]. A key component of the replication machinery is the RNA-dependent RNA polymerase ( $R d R p)$, also referred to as $3 \mathrm{D}$ polymerase $\left(3 \mathrm{D}^{\mathrm{pol}}\right)$ in picornaviruses. This protein is responsible for the synthesis of both plus- and minus-strand viral RNA [4]. Equine picornaviruses, formerly known as equine rhinoviruses 1 and 2, have been reclassified as equine rhinitis $A$ virus (ERAV) and equine rhinitis $B$ virus (ERBV). ERAV (formerly equine rhinovirus 1 [prototype ERAV.P393/ 76]), a member of the genus Aphthovirus in the family Picornaviridae, was first isolated in the United Kingdom in 1962 [5-7]. The genome organization and structure of ERAV is very similar to that of other Picornaviruses (e.g. foot-and-mouth disease virus). The second equine rhinitis virus, ERBV (formerly equine rhinovirus 2 [prototype P1436/71]) was first isolated in Switzerland and subsequent sequence determination resulted in it being classified in a new genus Erbovirus, also in the family Picornaviridae $[7,8]$. There are three ERBV serotypes (designated ERBV 1, 2 and 3) that are differentiated on the basis of their acid lability/stability, genetic sequences and neutralization by type-specific antisera. The ERBV1 and ERBV3 serotypes comprise two distinct phylogenetic groups, one of which is phenotypically acid labile (ERBV1; [9]) and the other is acid stable (ERBV3; [10]). Subsequently, a third equine rhinovirus virus (equine rhinovirus 3) was also isolated in Switzerland and following sequence analysis of its viral capsid proteins, it was shown to be a second serotype in the genus Erbovirus, and was designated as ERBV2 (prototype P313/75) $[9,11,12]$.

Strains of ERAV, ERBV1 and ERBV2 have been identified from both subclinical and clinical upper respiratory tract infections in horses worldwide [13-16]. Little is known about the pathogenesis of ERAV and ERBV, which could be attributable in part to the lack of suitable laboratory methods for the diagnosis of these infectious agents. Seroprevalence data reported by different investigators indicate that neutralizing antibodies to ERAV and ERBV can be found in $50 \%$ to $80 \%$ of horses worldwide and the seropositive percentage seems to be correlated with the age of the animals [15,17-20]. Most ERAV, ERBV1 and ERBV2 isolates were recovered from horses with acute febrile respiratory disease with clinical signs of high fever for 1-3 days, serous to mucopurulent nasal discharge, anorexia, leg edema and enlarged lymph nodes of the head and neck that were sensitive on palpation. A significant number of horses may carry and shed virus in their urine for an extended period of time [16]. Subclinical infection and subsequent seroconversion have also been reported [5,16,21,22].

The clinical signs of equine influenza virus (EIV), equine herpesvirus-1 and -4 (EHV-1 and EHV-4), equine adenovirus 1 (EAdV1), equine arteritis virus (EAV), and equine rhinitis $A$ and $B$ (ERAV, ERBV1, ERBV2) infections are very similar and resemble a number of other infectious and non-infectious equine respiratory diseases $[23,24]$. Accordingly, a provisional clinical diagnosis based solely on the respiratory signs must be confirmed by laboratory testing. Furthermore, rapid and accurate identification of these viruses is critical for the control of the diseases they cause. Therefore, the development of rapid, highly sensitive and specific diagnostic assays is essential for the identification and differentiation of ERAV and ERBV in infected horses during outbreaks of disease. In addition, such assays would facilitate epidemiological investigations.

Traditionally, ERAV and ERBV have been detected by virus isolation (VI) in susceptible cells lines such as African green monkey kidney (Vero) or rabbit kidney-13 (RK-13) cells. Sources of these viruses can include nasal swabs, blood, feces and urine $[16,25,26]$. VI can be challenging because some strains of these viruses may grow poorly in cell culture and may not give rise to visible cytopathic effect $[27,28]$. A modified culture medium supplemented with $\mathrm{MgCl}_{2}$ can enhance the growth of some ERBV strains, but it is unsuitable for diagnostic purposes due to lack of sensitivity [27]. Furthermore, successful VI frequently requires multiple blind passages and subsequent confirmation by electron microscopy or immunofluorescence testing in the case of noncytopathic strains. ERAV and ERBV infection can also be detected serologically by demonstration of a four-fold or greater rise in antibody titer between acute and convalescent (paired) sera by virus neutralization $[8,16,29]$ or complement fixation tests[13,30], however, serology might not be helpful in acute outbreak situations due to the time delay of the convalescent result. Furthermore, these traditional serologic techniques, although sensitive and specific, are time consuming and tedious. Several rapid molecular tests such as conventional RT-PCR 
Table 1 Primers and probes used in the rRT-PCR assays

\begin{tabular}{|c|c|c|c|c|}
\hline $\begin{array}{l}\text { rRT-PCR Assay } \\
\text { Name }\end{array}$ & $\begin{array}{l}\text { Target Genes } \\
\text { (GenBank Accession Number) }\end{array}$ & $\begin{array}{l}\text { Primer or } \\
\text { Probe Names }\end{array}$ & Sequence $5^{\prime}$ to $3^{\prime}$ and Nucleotide Location & $\begin{array}{l}\text { Length of Fragment } \\
\text { (bp) }\end{array}$ \\
\hline \multirow[t]{3}{*}{ ERAV } & 5'-UTR of ERAV (L43052) & ERAV F & AGCGGCK ${ }^{\mathbf{d}}$ TGCTGGATTTC (397-415) & 60 \\
\hline & & ERAV R & CATY' $^{\mathbf{e}}$ TYCAGCTTGGTGACA (438-457) & \\
\hline & & $\overline{\text { ERAV } \operatorname{Pr}}$ & FAM $^{\mathrm{b}}$-CGGTGCCATTGCT-MGB ${ }^{\mathrm{c}}(417-429)$ & \\
\hline \multirow[t]{3}{*}{ ERBV1 } & 5'-UTR of ERBV1 (NC_003983) & ERBV1 $\mathrm{F}$ & CCCCTT $^{f}$ CCCTGAAGATTGCT (148-167) & 61 \\
\hline & & ERBV1 R & GGCAAACGACCAACACATCA (190-209) & \\
\hline & & ERBV1 Pr & FAM-TTCTTCCAACTAAACCC-MGB (169-185) & \\
\hline ERBV2 & 5'-UTR of ERBV2 (NC_003077) & ERBV2 F & CCCCAACCCTTGAGATTGCT (148-167) & \\
\hline
\end{tabular}

${ }^{\mathrm{a}} \mathrm{F}=$ Forward primer. $\mathrm{R}=$ Reverse primer. $\mathrm{Pr}=$ Probe.

${ }^{\mathrm{b}}$ Reporter dye (FAM; 6-carboxyfluorescein) labeled nucleotide.

${ }^{\mathrm{C}}$ Nonfluorescent quencher dye (MGB ${ }^{\mathrm{TM}}$; minor groove binding) labeled nucleotide.

${ }^{\mathrm{d}} \mathrm{K}$ represents $\mathrm{G}$ or $\mathrm{T}$.

${ }^{\mathrm{e}} \mathrm{Y}$ represents $\mathrm{C}$ or $\mathrm{T}$.

${ }^{f}$ Nucleotide difference between the forward primers of ERBV1 and ERBV2 are in bold.

(cRT-PCR) and real-time RT-PCR (rRT-PCR) have been developed for ERAV and ERBV [27,31-33]. The primers used in these assays were located in the $3 \mathrm{D}^{\mathrm{pol}}, 3$ '-UTR, 5 -UTR or VP1-2A regions of the viral genome. In the present study, we developed a panel of three new rRTPCR assays for ERAV and ERBV targeting the 5'-UTR region of each viral genome, respectively. In addition, to facilitate more diagnostic flexibility, a panel of six cRTPCR assays targeting the $5^{\prime}$-UTR and $3 D^{\text {pol }}$ regions of ERAV or ERBV was also developed. This would allow diagnostic laboratories that do not have functional realtime RT-PCR assays to diagnose ERAV and ERBV infections in horses.

\section{Results and discussion}

Development of rRT-PCR assays for the detection of ERAV and ERBV

Three ERAV and ERBV specific primer and probe sets were developed targeting the conserved 5 '-UTR region of the viral genomes (Table 1). One primer and probe set was specific for ERAV (named ERAV rRT-PCR assay) and the primers were degenerated to accommodate nucleotide variations found in sequences that are available in GenBank $(\mathrm{n}=8)$. The second primer and probe set (named ERBV1 rRT-PCR assay) was specific for ERBV1 strain. A third assay (named ERBV2 rRT-PCR assay) consisted of the same reverse primer and probe sequences as in the ERBV1 assay with the exception that the forward primer was specific for ERBV2. The 4nucleotide difference in the forward primer between the ERBV1 and ERBV2 assays was designed to increase the likelihood of detection of ERBV2 strains. Three rRTPCR assays were initially tested with prototype strains of ERAV and ERBV obtained from the USDA's National Veterinary Services Laboratories (NVSL), Ames, IA. All the assays were optimized using RNA extracted from the prototype strains of ERAV and ERBV and with different primers and probe concentrations using TaqMan ${ }^{\circledR}$ onestep RT-PCR master mix in a checkerboard assay. The optimal primer and probe concentrations producing the greatest sensitivity and specificity for detection of ERAV and ERBV were selected for the final assay as described in the materials and methods section. The ERAV assay detected only the ERAV prototype strain with a mean cycle threshold $(\mathrm{Ct})$ of $21.79 \pm 0.30$ (ranging from 21.58 to 22.00) and no cross-reaction with the ERBV prototype

Table 2 Primers and probes used in the rRT-PCR assay developed by Quinlivan et al. (2010)

\begin{tabular}{|c|c|c|c|c|}
\hline $\begin{array}{l}\text { rRT-PCR Assay } \\
\text { Name }\end{array}$ & $\begin{array}{l}\text { Target Genes } \\
\text { (GenBank Accession Number) }\end{array}$ & $\begin{array}{l}\text { Primer or } \\
\text { Probe Names }^{a}\end{array}$ & Sequence $5^{\prime}$ to $3^{\prime}$ and Nucleotide Location & $\begin{array}{l}\text { Length of Fragment } \\
\text { (bp) }\end{array}$ \\
\hline \multirow[t]{3}{*}{ ERAV } & 5'-UTR of ERAV (NC_003982) & ERAV 468F & CCAGGTAACCGGACAGCG (468-485) & 118 \\
\hline & & ERAV 569R & GGCAGCGCTACCACAGG (569-585) & \\
\hline & & ERAV 508b & FAM $^{\mathrm{b}}$-CATTGCTCTGGATGGTGT-MGBC $(508-525)$ & \\
\hline \multirow[t]{3}{*}{ ERBV } & 5'-UTR of ERBV (NC_003983) & ERBV $77 \mathrm{~F}$ & TGATGCTTGGCTCTCAGAAA (77-96) & 132 \\
\hline & & ERBV $189 R$ & GCAAACGACCAACACATCAA (189-208) & \\
\hline & & ERBV 171b & FAM $^{\mathrm{b}}$-CTTCCAACTAAACCC-MGBC (171-185) & \\
\hline
\end{tabular}

${ }^{\mathrm{a}} \mathrm{F}=$ Forward primer. $\mathrm{R}=$ Reverse primer. $\mathrm{Pr}=$ Probe.

${ }^{\mathrm{b}}$ Reporter dye (FAM; 6-carboxyfluorescein) labeled nucleotide.

${ }^{\mathrm{C}}$ Nonfluorescent quencher dye (MGB ${ }^{\mathrm{TM}}$; minor groove binding) labeled nucleotide. 
strain was noted. Both ERBV rRT-PCR assays detected only the ERBV prototype strain, but not the ERAV strain, with a mean Ct value of $12.99 \pm 0.01$ (ranging from 12.98 to 13) for the ERBV1 rRT-PCR assay and $29.01 \pm 0.02$ (ranging from 29.00 to 29.03) for the ERBV2 rRT-PCR assay, respectively. Subsequently, the specificity of these assays was tested using a range of other equine respiratory viruses including EAV, EIV, EAdV1 and 2, EHV 1-5 and Salem virus. The assays were shown to be $100 \%$ specific with no cross-reactivity with nucleic acid extracted from the afore-mentioned equine respiratory pathogens.

The three assays were further evaluated for detection capability using 21 archived ERAV $(\mathrm{n}=11)$ or ERBV $(\mathrm{n}=10)$ isolates whose identity was previously confirmed in a one-way neutralization test using mono-specific rabbit antisera [16]. All three assays identified the ERV subtype accurately and no cross-reactivity between subtypes were observed. The mean $\mathrm{Ct}$ values of ERAV, ERBV1 and ERBV2 rRT-PCR assays are $24.53 \pm 3.45$ (ranging from 22 to 29), $29.50 \pm 3.58$ (ranging from 24 to 34 ) and 29.14 \pm 5.22 (ranging from 18 to 35), respectively. Both ERBV1 and ERBV2 rRT-PCR assays could detect two previously well characterized ERBV1 isolates (NS CW and 58-13 NVS) [9]. None of the ERBV1 or ERBV2 rRT-PCR assays were able to distinguish viral RNA between ERBV1 and ERBV2 serotypes tested in the study. Overall, the two assays designed to distinguish ERBV1 and ERBV2 serotypes were able to detect the NVSL prototype strain of ERBV, indicating that the nucleotide mismatches in the forward primer were not sufficiently definitive to provide serotype specificity. This was further confirmed by their inability to distinguish the archived isolates as ERBV1 or ERBV2 serotype.

Previously Quinlivan et al. (2010) developed two TaqMan ${ }^{\circledR}$ rRT-PCR assays targeting the conserved region of the 5'-UTR of the ERV genomes (Table 2) [33]. These two assays were also tested with RNA extracted from each of the two prototype strains of ERAV and ERBV, as well as TCF of 21 archived field isolates. The assay targeting ERAV could detect the ERAV prototype strain and the 11 ERAV positive isolates without cross-reacting with any ERBV samples. The mean $\mathrm{Ct}$ value was $15.31 \pm 1.29$ (ranging from 14 to 19), which was lower than the ERAV assay developed in our laboratory $(24.53 \pm 3.45$, [ranging from 22 to 29 ]), indicating that this published ERAV assay is more sensitive in detecting the field isolates than the ERAV rRT-PCR assay developed in this study. In contrast, the assay targeting ERBV could not detect any of the ERBV isolates or the prototype strain of ERBV. This assay also did not cross-react with ERAV strains evaluated in this study. However, the reagents used in this study were not identical to those reported in the original publication by Quinlivan et al.
(2010); this may also have contributed to the reduced sensitivity and failure to detect of ERBV RNA in the ERBV rRT-PCR assay. In order to provide a standardized protocol that can be easily applied in different laboratories, a commercial kit and manufacturer's recommended real-time RT-PCR cycle parameters were used in the current study.

\section{Development of CRT-PCR assays for the detection of ERAV and ERBV}

To provide more diagnostic options, we developed an additional panel of six cRT-PCR assays to target the 5'UTR and $3 D^{\text {pol }}$ regions of ERAV and ERBV (Table 3). All primers were designed to distinguish ERAV and ERBV subtypes and were initially tested with the prototype strains of ERAV and ERBV obtained from NVSL. All primer pairs could detect the prototype strains for which they were designed and the cRT-PCR products matched their predicted sizes (Figure 1). The authenticity of the cRT-PCR products was confirmed by sequencing. Subsequently, the primers were tested with the RNA extracted from archived infective ERV TCF specimens. Similar to the rRT-PCR results, the ERAV 5'UTR, ERAV Poly 1 and ERAV Poly 2 cRT-PCR assays could detect all the ERAV RNA from field isolates and did not cross-react with the RNA from ERBV isolates. The ERBV Poly 1 and ERBV Poly 2 cRT-PCR assays were also highly specific for the detection of RNA from ERBV isolates without cross-reacting with RNA from ERAV isolates. Sequence comparison analysis between the ERBV1 prototype P1436/71 (GenBank accession number X96871) and ERBV2 prototype P313/75 (GenBank accession number AF361253) revealed that these two strains shared $92.5 \%$ sequence identity in the $3 \mathrm{D}^{\mathrm{pol}}$ region which is consistent with the previous findings that the $3 \mathrm{D}^{\mathrm{pol}}$ region of ERBV is highly conserved and therefore commonly used for primer design [12,32]. The high sequence similarity between ERBV1 and ERBV2 in the $3 \mathrm{D}^{\mathrm{pol}}$ region is good for primer design in differentiating ERBV from ERAV; however, it may also prevent the successful differentiation of ERBV1 and ERBV2 serotypes. In contrast to the high sensitivity of ERBV cRTPCR assays targeting the $3 \mathrm{D}^{\mathrm{pol}}$ region, the ERBV cRTPCR assay targeting the 5'-UTR region could only detect 2 out of the 10 ERBV positive isolates (Table 4). All six assays were specific for ERV and did not react with other common equine respiratory viruses. Therefore, we concluded that the cRT-PCR assays that were developed could be used to distinguish ERAV from ERBV but not between ERBV serotypes.

Previously Black et al. (2007) developed four primers for the detection of ERBV RNA by RT nested-PCR assay [27]. We took these four primers and mix and matched them depending on their positions to generate four 
Table 3 Primers used in the CRT-PCR assays

\begin{tabular}{|c|c|c|c|c|}
\hline cRT-PCR Assay Name & Primer Names & Sequence $5^{\prime}$ to $3^{\prime}$ and Nucleotide Location (nt) & Genbank Accession Number & Reference \\
\hline \multirow[t]{2}{*}{ ERAV $5^{\prime} U T R$} & ERAV 5'UTR F & TCAGCCCCCTGTCATTGACT (341-360) & NC_003982 & This study \\
\hline & ERAV 5'UTR R & TGR ${ }^{\mathrm{a} T C A G G G C T G T A A C C A ~(769-786) ~}$ & & \\
\hline \multirow[t]{2}{*}{ ERAV Poly } & ERAV Poly F & TGGATGAAGTGGTTITTGC (6384-6402) & & \\
\hline & ERAV Poly R & CAGTCAAAGCCTGGTTGTCA (6502-6521) & & \\
\hline \multirow[t]{2}{*}{ ERAV Poly2 } & ERAV Poly F & TGGATGAAGTGGTTITTGC (6384-6402) & & \\
\hline & ERAV Poly R2 & ACTCTCATTGCATCAGCTGC (6977-6996) & & \\
\hline \multirow[t]{2}{*}{ ERBV 5' UTR } & ERBV 5'UTR F & TTTCGTTCCW ${ }^{\mathrm{b}}$ CTTTAGCR ${ }^{\mathrm{a}}$ GG (349-368) & NC_003983 & \\
\hline & ERBV 5'UTR R & TCAGATCCGCACTCTATGAAG (764-784) & & \\
\hline \multirow[t]{2}{*}{ ERBV OUTER1 } & ERBV OUTER F & TITTGATGCTTCACATTCTCC (7986-8006) & & [27] \\
\hline & ERBV OUTER R & CGCTGTACCCTCGGTCCTACTC (8746-8767) & & \\
\hline \multirow[t]{2}{*}{ ERBV OUTER2 } & ERBV OUTER F & TITTGATGCTTCACATTCTCC (7986-8006) & & \\
\hline & ERBV INNER R & GCCTCGGCGAGTGAAGAG (8721-8739) & & \\
\hline \multirow[t]{2}{*}{ ERBV INNER1 } & ERBV INNER F & CTTACTAY ${ }^{\complement}$ GAATGTGARGGGGC (8117-8138) & & \\
\hline & ERBV INNER R & GCCTCGGCGAGTGAAGAG (8721-8739) & & \\
\hline \multirow[t]{2}{*}{ ERBV INNER2 } & ERBV INNER F & CTTACTAYGAATGTGARGGGGC (8117-8138) & & \\
\hline & ERBV OUTER R & CGCTGTACCCTCGGTCCTACTC (8746-8767) & & \\
\hline \multirow[t]{2}{*}{ ERBV Poly1 } & ERBV Poly F & TTGAGTTGACCCTTCTGCA (7409-7427) & & This study \\
\hline & ERBV Poly R & TCATACTCTGAAATGR ${ }^{\mathbf{a}} \mathbf{K}^{\mathrm{d}}$ TCCATTG (7530-7553) & & \\
\hline \multirow[t]{2}{*}{ ERBV Poly2 } & ERBV Poly F & TTGAGTTGACCCTTCTGCA (7409-7427) & & \\
\hline & ERBV Poly R2 & GCTGAACCAATGCCTAATCC (7879-7898) & & \\
\hline
\end{tabular}

a $R$ represents $A$ or $G$.

${ }^{\mathrm{b}} \mathrm{W}$ represents $\mathrm{A}$ or $\mathrm{T}$.

${ }^{c} \mathrm{Y}$ represents $\mathrm{C}$ or $\mathrm{T}$.

${ }^{\mathrm{d}} \mathrm{K}$ represents $\mathrm{G}$ or $\mathrm{T}$.

one-step cRT-PCR assays (Table 3). These four assays (ERBV OUTER 1, ERBV OUTER 2, ERBV INNER 1 and ERBV INNER 2) could distinguish all ERBV positive isolates from ERAV isolates included in this study. The application of one-step RT-PCR has a greater advantage over the nested RT-PCR because it eliminates the possibility of cross-contamination between samples and reduces the turnaround time.

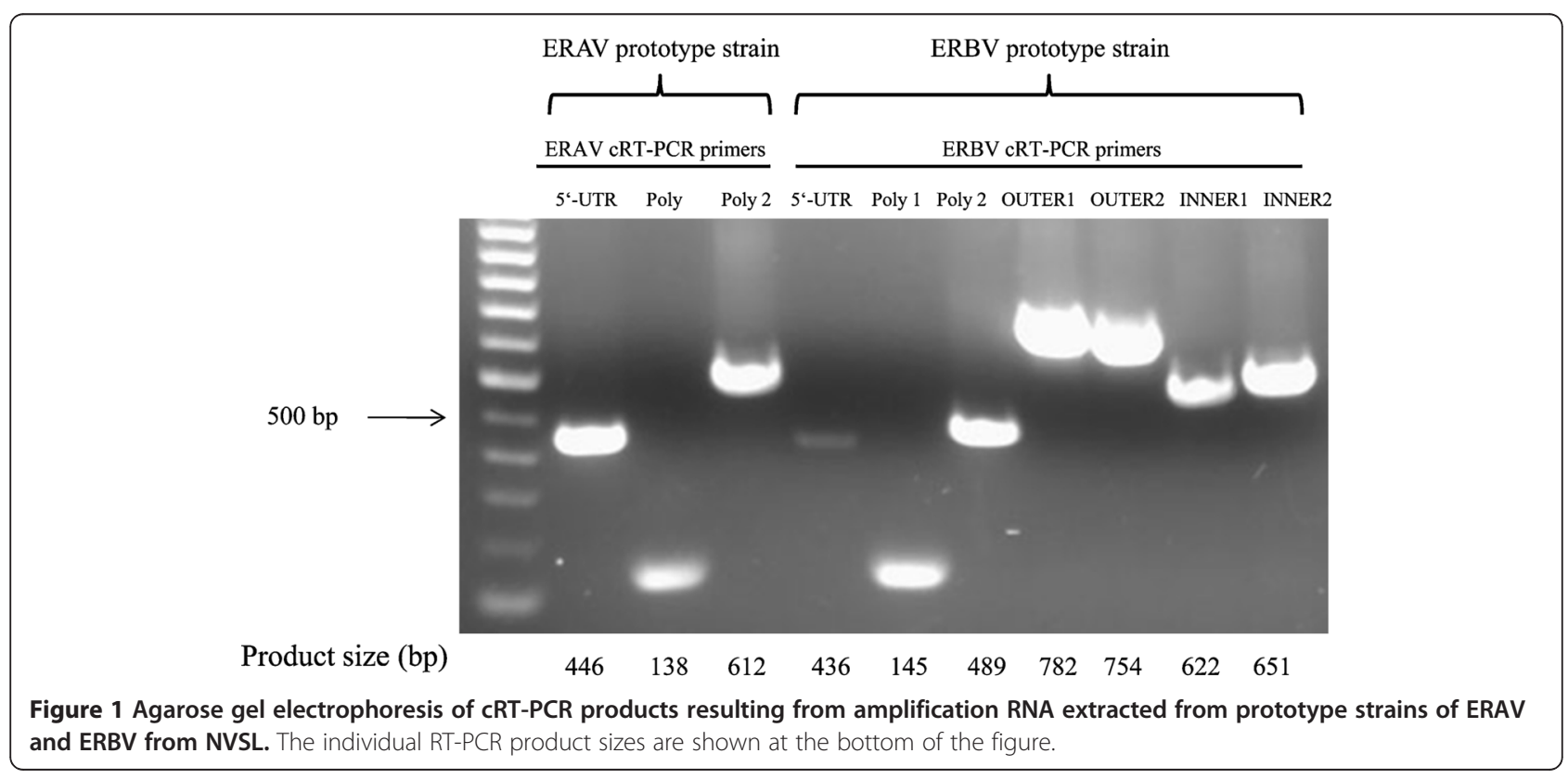


Table 4 Archived ERAV and ERBV isolates tested with rRT-PCR assays and CRT-PCR assays

Sample

Source of TCF rRT-PCR Assays

ERAV ERBV

\begin{tabular}{|c|c|c|c|c|c|c|c|c|c|c|c|c|c|c|}
\hline & & \multirow{2}{*}{$\frac{\text { ERAV }}{\text { ERAV }}$} & \multicolumn{2}{|c|}{ ERBV } & \multicolumn{3}{|c|}{ ERAV } & \multicolumn{7}{|c|}{ ERBV } \\
\hline & & & ERBV1 & ERBV2 & $\begin{array}{l}\text { ERAV } \\
\text { 5'-UTR }\end{array}$ & $\begin{array}{l}\text { ERAV } \\
\text { Poly }\end{array}$ & $\begin{array}{l}\text { ERAV } \\
\text { Poly } 2\end{array}$ & $\begin{array}{l}\text { ERBV } \\
\text { 5'-UTR }\end{array}$ & $\begin{array}{l}\text { ERBV } \\
\text { Poly } 1\end{array}$ & $\begin{array}{l}\text { ERBV } \\
\text { Poly } 2\end{array}$ & $\begin{array}{l}\text { ERBV } \\
\text { OUTER } 1^{c}\end{array}$ & $\begin{array}{l}\text { ERBV } \\
\text { OUTER } 2^{c}\end{array}$ & $\begin{array}{l}\text { ERBV } \\
\text { INNER } 1^{c}\end{array}$ & $\begin{array}{l}\text { ERBV } \\
{\text { INNER } 2^{C}}^{c}\end{array}$ \\
\hline \multicolumn{15}{|l|}{ Serotype ERAV } \\
\hline ERAV & $\mathrm{NVSL}^{\mathrm{a}}$ & + & - & - & + & + & + & - & - & - & - & - & - & - \\
\hline PERV, P4 2004 A & $\mathrm{GERC}^{\mathrm{b}}$ & + & - & - & + & + & + & - & - & - & - & - & - & - \\
\hline Plowright,P4 2004 A & GERC & + & - & - & + & + & + & - & - & - & - & - & - & - \\
\hline T3 isolate P10/2004 A & GERC & + & - & - & + & + & + & - & - & - & - & - & - & - \\
\hline T10 isolate P9/2004 A & GERC & + & - & - & + & + & + & - & - & - & - & - & - & - \\
\hline 945 isolate P4/2004 A & GERC & + & - & - & + & + & + & - & - & - & - & - & - & - \\
\hline ERV-1 (A) Plowright P4 & GERC & + & - & - & + & + & + & - & - & - & - & - & - & - \\
\hline ERV-1 (A) PERV P4 & GERC & + & - & - & + & + & + & - & - & - & - & - & - & - \\
\hline Amp 87-73-69-945 & GERC & + & - & - & + & + & + & - & - & - & - & - & - & - \\
\hline NS-T3 & GERC & + & - & - & + & + & + & - & - & - & - & - & - & - \\
\hline NS-T10 & GERC & + & - & - & + & + & + & - & - & - & - & - & - & - \\
\hline U-187 & GERC & + & - & - & + & + & + & - & - & - & - & - & - & - \\
\hline \multicolumn{15}{|l|}{ Serotype ERBV } \\
\hline ERBV & NVSL & - & + & + & - & - & - & + & + & + & + & + & + & + \\
\hline Swiss isolate P6 2004 B & GERC & - & + & + & - & - & - & - & + & + & + & + & + & + \\
\hline$\overline{N S C W}$ & GERC $^{d}$ & - & + & + & - & - & - & + & + & + & + & + & + & + \\
\hline U-198V & GERC & - & + & + & - & - & - & - & + & + & + & + & + & + \\
\hline NS-SD & GERC & - & + & + & - & - & - & - & + & + & + & + & + & + \\
\hline Mare 189 & GERC & - & + & + & - & - & - & - & + & + & + & + & + & + \\
\hline 51-12NVS & GERC & - & + & + & - & - & - & - & + & + & + & + & + & + \\
\hline 57-10NVS & GERC & - & + & + & - & - & - & - & + & + & + & + & + & + \\
\hline 57-11NVS & GERC & - & + & + & - & - & - & - & + & + & + & + & + & + \\
\hline 57-13NVS & GERC & - & + & + & - & - & - & - & + & + & + & + & + & + \\
\hline 58-13 NVS & $\mathrm{GERC}^{\mathrm{d}}$ & - & + & + & - & - & - & - & + & + & + & + & + & + \\
\hline
\end{tabular}

${ }^{a}$ National Veterinary Services Laboratories, Ames, IA.

${ }^{\mathrm{b}}$ Maxwell H. Gluck Equine Research Center. All archived samples from GERC were obtained from the late Dr. William H. McCollum.

${ }^{\mathrm{c}}$ These assays were developed by Black et al. (2007).

d These two TCF samples were also included in a study done by Black et al. (2005). 
Table 5 Detection limit of virus particles with rRT-PCR assays and CRT-PCR assays ${ }^{a}$

\begin{tabular}{|c|c|c|c|c|c|c|c|c|c|c|c|c|c|c|}
\hline \multirow[t]{4}{*}{ ERV Strains ${ }^{\mathbf{b}}$} & \multirow[t]{4}{*}{ TCF Titer } & \multicolumn{13}{|c|}{ Assay name } \\
\hline & & \multicolumn{3}{|c|}{ rRT-PCR Assays } & \multicolumn{10}{|c|}{ cRT-PCR Assays } \\
\hline & & \multirow{2}{*}{$\frac{\overline{\text { ERAV }}}{\overline{\text { ERAV }}}$} & \multicolumn{2}{|c|}{ ERBV } & \multicolumn{3}{|c|}{ ERAV } & \multicolumn{7}{|c|}{ ERBV } \\
\hline & & & ERBV1 & ERBV2 & $\begin{array}{l}\text { ERAV } \\
\text { 5'-UTR }\end{array}$ & $\begin{array}{l}\text { ERAV } \\
\text { POLY1 }\end{array}$ & $\begin{array}{l}\text { ERAV } \\
\text { POLY2 }\end{array}$ & $\begin{array}{l}\text { ERBV } \\
\text { 5'-UTR }\end{array}$ & $\begin{array}{l}\text { ERBV } \\
\text { OUTER } 1^{d}\end{array}$ & $\begin{array}{l}\text { ERBV } \\
\text { OUTER } 2^{d}\end{array}$ & 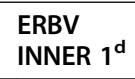 & $\begin{array}{l}\text { ERBV } \\
{\text { INNER } 2^{d}}^{\text {d }}\end{array}$ & $\begin{array}{l}\text { ERBV } \\
\text { Poly } 1\end{array}$ & $\begin{array}{l}\text { ERBV } \\
\text { Poly } 2\end{array}$ \\
\hline ERAV & $10^{-7}$ & $10^{-6}$ & $N A^{c}$ & $\mathrm{NA}$ & $10^{-6}$ & $10^{-5}$ & $10^{-5}$ & $\mathrm{NA}$ & $\mathrm{NA}$ & $\mathrm{NA}$ & NA & NA & $\mathrm{NA}$ & NA \\
\hline$\overline{\text { ERBV }}$ & $10^{-7}$ & NA & $10^{-7}$ & $10^{-4}$ & NA & NA & NA & $10^{-1}$ & $10^{-5}$ & $10^{-4}$ & $10^{-4}$ & $10^{-4}$ & $10^{-4}$ & $10^{-5}$ \\
\hline
\end{tabular}

a Serial decimal dilutions of ERAV and ERBV were tested in a comparison study by virus isolation in cell culture, rRT-PCR and standard RT-PCR assays. Numbers shown on the table represent the serial virus dilution.

${ }^{b}$ ERAV and ERBV prototype strains were obtained from NVSL.

c Not applicable.

${ }^{d}$ The primers used in these four assays were obtained from a nested RT-PCR developed by Black et al. (2007).

\section{Comparison of sensitivities of the rRT-PCR and CRT-PCR assays}

Using serial decimal dilutions $\left(10^{-1}\right.$ to $\left.10^{-10}\right)$ of the TCF containing ERAV and ERBV prototype strains, the detection limits of all rRT-PCR and cRT-PCR assays were compared (Table 5, Figure 2). Viral RNA from each of the serial dilutions was eluted in $50 \mu$ l of nuclease free water and $5 \mu \mathrm{l}$ was tested in duplicate in both rRT-PCR and CRT-PCR assays. The plaque number in the highest dilution was used to calculate the number of infectious particles that can be detected by each assay. The amplification efficiency of the three ERAV, ERBV1 and ERBV2 rRT-PCR assays was 97.0\%, 94.8\% and 94.2\%, respectively, calculated according to a previously described method (Figure 2) [34]. The ERAV rRT-PCR assay and ERAV 5'-UTR cRT-PCR assay could detect viral RNA up to $10^{-6}$ dilution of ERAV in TCF which is approximately $1 \mathrm{pfu} / \mathrm{ml}$ infectious virus particles. The other two ERAV
cRT-PCR assays (ERAV Poly1 and ERAV Poly 2) were 10 -fold less sensitive $\left(10^{-5}\right.$ virus dilution, which is approximately $10 \mathrm{pfu} / \mathrm{ml}$ ) as compared to the rRT-PCR and CRT-PCR assays targeting the 5'-UTR regions (Figure 2). The ERBV1 rRT-PCR assay could detect ERBV viral RNA up to $10^{-7}$ dilution which equals $1.2 \mathrm{pfu} / \mathrm{ml}$ infectious virus particles. The third rRT-PCR assay targeting ERBV2 was 3 logs less sensitive compared to the ERBV1 rRT-PCR assay and could only detect more than $550 \mathrm{pfu} / \mathrm{ml}$ infectious virus particles. This suggests that the ERBV1 rRT-PCR assay is more suitable for the detection of ERBV in clinical samples. All the ERBV cRT-PCR assays except ERBV 5'-UTR cRT-PCR assay could detect 10 to $30 \mathrm{pfu} / \mathrm{ml}$ infectious virus particles $\left(10^{-5}\right.$ to $10^{-6}$ dilutions). The ERBV $5^{\prime}$-UTR cRT-PCR assay was the least sensitive and could only detect virus in the $10^{-1}$ dilution of TCF $\left(2.75 \times 10^{5} \mathrm{pfu} / \mathrm{ml}\right.$ infectious virus particles).

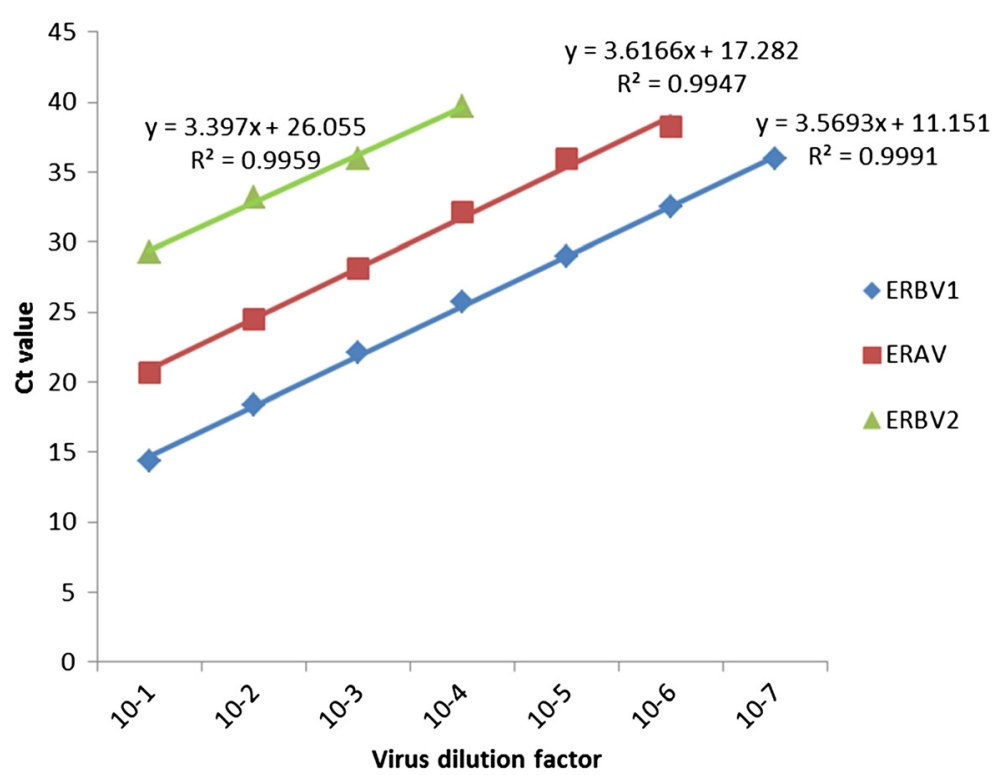

Figure 2 Comparison of detection sensitivity of the three rRT-PCR assays using ERAV or ERBV prototype strains from NVSL (ERAV rRT$\mathrm{PCR}$ assay $\left[y=3.4543 x+17.373, R^{2}=0.9949\right]$, ERBV1 rRT-PCR assay $\left[y=3.4682 x+11.719, R^{2}=0.9997\right]$ and ERBV2 rRT-PCR assay $\left.\left[y=3.397 x+26.055, R^{2}=0.9959\right]\right)$. 
Overall, the rRT-PCR assays were more sensitive than the cRT-PCR assays. There was approximately a 10 -fold difference in the limit between the rRT-PCR and cRTPCR assays in detecting ERAV strains. There was a significant difference in the sensitivity of the rRT-PCR and cRT-PCR assays targeting the ERBV strains. The ERBV 5'-UTR cRT-PCR assay was the least sensitive among all the developed assays. This might be explained by the fact that the reverse primer of the ERBV 5'-UTR cRTPCR assay was located in the higher order internal ribosome entry site [7]. This complex sequence region may prevent efficient binding of the reverse primer to target sequences. However, no plausible explanation can be provided for the high sensitivity of the ERAV 5 '-UTR CRT-PCR assay which was targeting the similar region as compared to ERBV.

Although ERAV and ERBV infections are considered a common disease in horses, limited data are available about the pathogenesis and disease prevalence, which may be due in part to the absence of suitable diagnostic methods for these infections [13-19,28,35,36]. Currently, there are only a few molecular diagnostic tests available for the detection of these viruses including a duplex rRT-PCR developed by Mori et al. (2009) [32] and single rRT-PCR assays for ERAV or ERBV developed by Quinlivan et al. (2010) [33]. The duplex rRT-PCR by Mori et al. (2009) was developed to differentiate ERAV from ERBV, but when tested, none of the samples were positive for ERAV [32]. Therefore the detection capability for ERAV using this duplex rRT-PCR assay is questionable. The single rRT-PCR assays developed by Quinlivan et al. (2010) detected 30 ERAV and 5 ERBV positives among 300 nasal swab samples collected over a 7 year period [33]. As we discussed above, the ERBV rRT-PCR assay developed in that study was unable to detect any ERBV isolates tested in this study using the current cycling conditions and rRT-PCR reagents. The assays developed in our study were tested with a limited number of well-characterized ERAV and ERBV isolates [9,27]. Therefore, the authors of this manuscript admit that prior to the application of the assays on a routine diagnostic basis, both would need to be more fully evaluated using a larger number of clinical specimens positive for both ERAV and ERBV.

\section{Conclusions}

In the current study, we developed one rRT-PCR assay and three cRT-PCR assays for the detection of ERAV and three rRT-PCR assays and three cRT-PCR assays for ERBV. Twenty-one archived ERAV or ERBV field isolates were used to evaluate the detection capability of the assays. Both the rRT-PCR and cRT-PCR assays designed for ERAV or ERBV could detect the serotype specific isolates without cross-reacting with other equine viral pathogens. Comparison of the respective sensitivities of rRT-PCR assays and cRT-PCR assays confirmed that the rRT-PCR assays have the same or greater sensitivity in detecting ERV in serial decimal dilutions of infective TCFs. Overall, the newly developed assays provide valuable tools for the detection of ERAV and ERBV.

\section{Methods}

\section{Cells and viruses}

The high passage RK-13 cell line (RK-13 KY; passage level 399-409) was maintained in Eagle's minimum essential medium (EMEM) supplemented with 10\% ferritin-supplemented bovine calf serum (Hyclone Laboratories, Inc., Logan, UT), $1 \%$ penicillin and streptomycin, and $0.1 \%$ amphotericin B $(1,000 \mu \mathrm{g} / \mathrm{ml})$. The overlay medium used for inoculated cultures was $0.75 \%$ carboxymethylcellulose (CMC) (Sigma-Aldrich, St. Louis, $\mathrm{MO}$ ) in supplemented EMEM. All of the other reagents were obtained from Mediatech, Inc., Herndon, VA.

Twenty-one TCF samples containing ERAV, ERBV1 and ERBV2 were included in this study. These samples were previously isolated from nasal swabs and urine samples from horses and characterized by the late Dr. William H. McCollum at the Maxwell H. Gluck Equine Research Center, University of Kentucky. The prototype strains of ERAV (NVSL-0600EDV8501) and ERBV (NVSL-0610EDV85010) from NVSL, Ames, IA were also included in the study. Virus working stocks were produced by propagating the viruses in RK-13 cells as described previously.

To determine the specificity of the rRT-PCR and cRTPCR assays, viral nucleic acid from each of the following equine viral pathogens was included in the study: equine arteritis virus (ATCC VR-796), equine herpesviruses 1-5 (EHV-1 [ATCC VR-700], EHV-2 [ATCC VR-701], EHV3 [ATCC VR-352], EHV-4 [ATCC VR-2230], and EHV-5 [37]), equine adenovirus 1 (NVSL-001EDV8401) and 2 (University of Kentucky Veterinary Diagnostic Laboratory), equine influenza virus (EIV) type A1 (equine/Prague/1/56 [H7N7]; NVSL-021IDV9201) and A2 (equine/Miami/63/ [H3N8]; NVSL-060IDV0501], equine/Kentucky/81 [H3N8; NVSL-040IDV0001], equine/Alaska//91 [H3N8; NVSL020IDV9101]), and Salem virus, a novel paramyxovirus of horses [38]. The EHV-5 and Salem virus were kindly provided by Dr. Stephen Bell at University of California, Davis, CA and Dr. Edward Dubovi, Cornell University, Ithaca, NY, respectively.

\section{RNA extraction}

Viral RNA was prepared from virus-infective tissue culture fluid (TCF) using the MagMAX ${ }^{\mathrm{m}}$-96 Viral RNA Isolation Kit (Applied Biosystems, Forest City, CA) 
according to the manufacturer's instructions. Briefly, TCF samples were microcentrifuged at $13,800 \times \mathrm{g}$ for $2 \mathrm{~min}$, and $50 \mu \mathrm{l}$ of supernatant was removed and used for nucleic acid extraction. The viral nucleic acid was eluted in $50 \mu \mathrm{l}$ nuclease free water and stored at $-80^{\circ} \mathrm{C}$.

\section{Primers and probes}

The conserved and variable regions of each equine rhinitis virus serotype (ERAV and ERBV) have been determined by alignment of 12 sequences ( 8 ERAV [GenBank accession numbers: L43052, DQ272127, NC_003982, X96870, DQ272578, DQ272577, DQ268580 and DQ272128], 2 ERBV1 [GenBank accession numbers: NC_003983 and X96871] and 2 ERBV2 [GenBank accession numbers: AF361253 and NC_003077]) available in GenBank. The rRT-PCR fluorescent TaqMan ${ }^{\circledR} \mathrm{MGB}^{\mathrm{TM}}$ (minor groove binding) probes and forward and reverse primers for ERAV, ERBV1 and ERBV2 were designed to target the conserved regions in 5'-UTR of each strain using Primer Express ${ }^{\mathrm{TM}}$ software (Applied Biosystems, Foster City, CA) (Table 1). Similarly, the cRT-PCR forward and reverse primers from both serotypes were designed to target the 5 -UTR and $3 \mathrm{D}^{\mathrm{pol}}$ regions of the genome using Vector NTI (Applied Biosystems, Foster City, CA). The four primers from a nested RT-PCR assay developed by Black et al. (2007) were included in the study as four, one-step cRT-PCR assays. Two rRT-PCR assays described by Quinlivan et al. (2010) were compared to the assays described in this manuscript (Table 2).

\section{One-step rRT-PCR assay}

The one-step TaqMan ${ }^{\circledR}$ rRT-PCR assay was performed using the TaqMan One-Step RT-PCR Master Mix in a 7500 Fast Real-Time PCR System as previously described [39]. Every sample was tested in duplicate in each assay. Briefly, $25 \mu \mathrm{l}$ of RT-PCR mixture for each reaction contained $12.5 \mu \mathrm{l}$ of $2 \times$ Master Mix without UNG (uracil-N-glycosylase), $0.625 \mu \mathrm{l}$ of $40 \times$ MultiScribe and RNase Inhibitor Mix, $0.45 \mu \mathrm{l}$ of $50 \mu \mathrm{M}$ forward and reverse primers (final concentration $900 \mathrm{nM}$ ), $0.625 \mu \mathrm{l}$ of $10 \mu \mathrm{M}$ probe (final concentration $250 \mathrm{nM}$ ), $5.35 \mu \mathrm{l}$ of nuclease free water, and $5 \mu$ l of test sample RNA. The following thermocycling conditions were used under standard mode as per manufacturer's recommendation: $30 \mathrm{~min}$ at $48^{\circ} \mathrm{C}, 10 \mathrm{~min}$ at $95^{\circ} \mathrm{C}$, followed by 40 cycles at $95^{\circ} \mathrm{C}$ for $15 \mathrm{sec}$ and $60^{\circ} \mathrm{C}$ for $1 \mathrm{~min}$. Each RT-PCR run included a control without RNA (containing the reaction mix with $5 \mu \mathrm{l}$ of water [no template control]) and positive controls containing ERAV or ERBV RNA.

\section{CRT-PCR assay and sequencing analysis}

The cRT-PCR was performed using a Qiagen OneStep RT-PCR kit (Qiagen, Santa Clara, CA) and $5 \mu$ l of test sample RNA in a mastercycler gradient thermal cycler (Eppendorf, Westbury, NY) according to the manufacturer's recommendation. Briefly, $50 \mu \mathrm{l}$ of RT-PCR reaction contains $10 \mu \mathrm{l}$ of $5 \times$ Qiagen OneStep RT-PCR buffer, $2 \mu \mathrm{l}$ of Qiagen OneStep RT-PCR enzyme mix, $2 \mu \mathrm{l}$ of $10 \mathrm{mM}$ dNTP mix (final concentration $0.4 \mathrm{mM}$ ), $1 \mu \mathrm{l}$ of RNase Inhibitor, $1 \mu \mathrm{l}$ of each of the forward and reverse primers, $28 \mu \mathrm{l}$ of nuclease free water and $5 \mu \mathrm{l}$ of RNA template. The following thermal cycler conditions were used: $50^{\circ} \mathrm{C}$ for $30 \mathrm{~min}, 95^{\circ} \mathrm{C}$ for $15 \mathrm{~min}$, followed by 40 cycles of $30 \mathrm{sec} 94^{\circ} \mathrm{C}$ denaturation, $30 \mathrm{sec} 50^{\circ} \mathrm{C}$ annealing, $1 \mathrm{~min} 72^{\circ} \mathrm{C}$ extension with a $10 \mathrm{~min} 72^{\circ} \mathrm{C}$ final extension.

The authenticity of the cRT-PCR products amplified from ERAV or ERBV NVSL prototype strains were sequenced using the primers which were used to amplify the products. The sequence data were analyzed using Aligner version 1.5.2 (CodonCode, Dedham, MA) software program.

\section{Determination of detection limits of rRT-PCR and CRT-PCR assays}

Using serial decimal dilutions $\left(10^{-1}\right.$ to $\left.10^{-10}\right)$ of ERAV and ERBV prototype strains (NVSL-0600EDV8501 and NVSL-0610EDV85010, respectively), the detection limits of the rRT-PCR and cRT-PCR assays were evaluated. To minimize inter-assay variability, equal aliquots of each dilution were used in all three assays. Briefly, $5 \mu \mathrm{l}$ of RNA extracted from $50 \mu \mathrm{l}$ of each decimal dilution were used in rRT-PCR and cRT-PCR assays as described above. RNA was run in duplicate in rRT-PCR assays, and both cRT-PCR and rRT-PCR assays were repeated three times independently.

\section{Authors' contributions}

UBR designed the study and supervised all the laboratory procedures. ZL extracted nucleic acids, developed and performed both rRT-PCR and CRT-PCR assays with prototype viruses. She wrote the manuscript with UBR. JW along with ZL performed rRT-PCR and CRT-PCR assays using archived TCF samples. PJT along with the late Dr. McCollum performed the isolation and characterization of ERAV and ERBV used in this study. All authors read and approved the final manuscript.

\section{Acknowledgements}

This study was supported by funds from the American Quarter Horse Association, the Frederick Van Lennep Chair endowment fund at the Maxwell H. Gluck Equine Research Center and the Kentucky Agricultural Experiment Station, College of Agriculture, University of Kentucky. Dr. Zhengchun Lu is the recipient of a Geoffrey C. Hughes Foundation graduate fellowship. We thank Jessica B. Gusler for her technical support.

Received: 12 April 2012 Accepted: 3 July 2012

Published: 25 July 2012

\section{References}

1. Stanway G, Brown F, Christian P: Family picornaviridae. In Virus Taxonomy: Eighth Report of the International Committee on Taxonomy of Viruses. Edited by Fauquet CM, Mayo MA, Maniloff J, Desselberger U, Ball LA. San Diego: Elsevier Academic Press; 2005:757-778.

2. Steil BP, Barton DJ: Cis-active RNA elements (CREs) and picornavirus RNA replication. Virus Res 2009, 139(2):240-252. 
3. Paul AV: Possible unifying mechanism of picornavirus genome replication. In Molecular Biology of Picornaviruses. Edited by Semler BL, Wimmer E. Washington: ASM Press; 2002:227-246.

4. Kok CC, McMinn PC: Picornavirus RNA-dependent RNA polymerase. Int J Biochem Cell Biol 2009, 41(3):498-502.

5. Plummer G: An equine respiratory virus with enterovirus properties. Nature 1962, 195:519-520.

6. Li F, Browning GF, Studdert MJ, Crabb BS: Equine rhinovirus 1 is more closely related to foot-and-mouth disease virus than to other picornaviruses. Proc Natl Acad Sci U S A 1996, 93(3):990-995.

7. Wutz G, Auer H, Nowotny N, Grosse B, Skern T, Kuechler E: Equine rhinovirus serotypes 1 and 2: relationship to each other and to aphthoviruses and cardioviruses. J Gen Virol 1996, 77(Pt 8):1719-1730.

8. Steck F, Hofer B, Schaeren B, Nicolet J, Gerber H: Equine rhinoviruses: new serotypes. In the Fourth International Conference on Equine Infectious Diseases: 1978; New Jersey, USA.: Veterinary Publication; 1978:321-328.

9. Black WD, Hartley CA, Ficorilli NP, Studdert MJ: Sequence variation divides Equine rhinitis $B$ virus into three distinct phylogenetic groups that correlate with serotype and acid stability. J Gen Virol 2005, 86(Pt 8):2323-2332.

10. Horsington JJ, Gilkerson JR, Hartley CA: Identification of mixed equine rhinitis $B$ virus infections leading to further insight on the relationship between genotype, serotype and acid stability phenotype. Virus Res 2011, 155(2):506-513.

11. Black WD, Studdert MJ: Formerly unclassified, acid-stable equine picornaviruses are a third equine rhinitis $B$ virus serotype in the genus Erbovirus. J Gen Virol 2006, 87(Pt 10):3023-3027.

12. Huang JA, Ficorilli N, Hartley CA, Wilcox RS, Weiss M, Studdert MJ: Equine rhinitis B virus: a new serotype. J Gen Virol 2001, 82(Pt 11):2641-2645.

13. Burrell MH, Wood JL, Whitwell KE, Chanter N, Mackintosh ME, Mumford JA: Respiratory disease in thoroughbred horses in training: the relationships between disease and viruses, bacteria and environment. Vet Rec 1996, 139(13):308-313.

14. Carman S, Rosendal S, Huber L, Gyles C, McKee S, Willoughby RA, Dubovi E, Thorsen J, Lein D: Infectious agents in acute respiratory disease in horses in Ontario. J Vet Diagn Investig 1997, 9(1):17-23.

15. Black WD, Wilcox RS, Stevenson RA, Hartley CA, Ficorilli NP, Gilkerson JR, Studdert MJ: Prevalence of serum neutralising antibody to equine rhinitis A virus (ERAV), equine rhinitis B virus 1 (ERBV1) and ERBV2. Vet Microbiol 2007, 119(1):65-71

16. McCollum WH, Timoney PJ: Studies on the seroprevalence and frequencey of equine rhinovirus-I and -II infection in normal horse urine. In Equine Infectious Diseases VI. Edited by Plowright W, Rossdale PD, Wade JF. Cambridge: R \& W Publications; 1992:83-87.

17. Hartley CA, Ficorilli N, Dynon K, Drummer HE, Huang JA, Studdert MJ: Equine rhinitis A virus: structural proteins and immune response. J Gen Virol 2001, 82(Pt 7):1725-1728.

18. Kriegshauser G, Deutz A, Kuechler E, Skern T, Lussy H, Nowotny N: Prevalence of neutralizing antibodies to Equine rhinitis $A$ and $B$ virus in horses and man. Vet Microbiol 2005, 106(3-4):293-296.

19. Studdert MJ, Gleeson $L$ : Isolation and characterisation of an equine rhinovirus. Zentralb/ Veterinarmed B 1978, 25(3):225-237.

20. Diaz-Mendez A, Viel L, Hewson J, Doig P, Carman S, Chambers T, Tiwari A, Dewey C: Surveillance of equine respiratory viruses in Ontario. Can J Vet Res 2010, 74(4):271-278.

21. Fukunaga $Y$, Kumanomido T, Kamada M, Wada R: Equine picornavirus: isolation of virus from the oral cavity of healthy horses. Bull Equine Res Inst 1983, 20:103-109.

22. Johnson DJ, Ostlund EN, Palmer TJ, Fett KL, Schmitt BJ: Isolation of equine rhinitis A virus from horse semen contaminated with urine. J Vet Diagn Investig 2012, 24(4):801-803.

23. Powell DG, Timoney PJ, Murphy T, Allen G, Donahue JM, Wilson J, Tudor L, Ferris K, Kawaoka Y: The application of advanced molecular techniques to investigate epizootics of infectious disease in the equine population. Acta Vet Scand Suppl 1988, 84:337-339.

24. Powell DG: Viral respiratory disease of the horse. Vet Clin N Am Equine Pract 1991, 7(1):27-52.

25. Plummer G, Kerry JB: Studies on an equine respiratory virus. Vet Rec 1962 , 74:967-970

26. Hoffer B, Steck F, Gerber H, Loher J, Nicolet J, Paccaud MF: An investigation of the etiology of viral respiratory disease in a remount depot. In $3 r d$
International Conference of Equine Infectious Disease: 1972; Karger, Basel. 1972:527-545

27. Black WD, Hartley CA, Ficorilli NP, Studdert MJ: Reverse transcriptasepolymerase chain reaction for the detection equine rhinitis $B$ viruses and cell culture isolation of the virus. Arch Virol 2007, 152(1):137-149.

28. Li F, Drummer HE, Ficorilli N, Studdert MJ, Crabb BS: Identification of noncytopathic equine rhinovirus 1 as a cause of acute febrile respiratory disease in horses. J Clin Microbiol 1997, 35(4):937-943.

29. Burrows R: Laboratory diagnosis of some virus infections of the upper respiratory tract of the horse. Equine Vet J 1968, 1:32-36.

30. Klaey M, Sanchez-Higgins M, Leadon DP, Cullinane A, Straub R, Gerber H: Field case study of equine rhinovirus 1 infection: clinical signs and clinicopathology. Equine Vet J 1998, 30(3):267-269.

31. Dynon K, Varrasso A, Ficorilli N, Holloway S, Reubel G, Li F, Hartley C, Studdert M, Drummer H: Identification of equine herpesvirus 3 (equine coital exanthema virus), equine gammaherpesviruses 2 and 5 , equine adenoviruses 1 and 2, equine arteritis virus and equine rhinitis $\mathrm{A}$ virus by polymerase chain reaction. Aust Vet J 2001, 79(10):695-702.

32. Mori A, De Benedictis P, Marciano S, Zecchin B, Zuin A, Capua I, Cattoli G Development of a real-time duplex TaqMan-PCR for the detection of Equine rhinitis A and B viruses in clinical specimens. J Virol Methods 2009, 155(2):175-181.

33. Quinlivan M, Maxwell G, Lyons P, Arkins S, Cullinane A: Real-time RT-PCR for the detection and quantitative analysis of equine rhinitis viruses. Equine Vet J 2010, 42(2):98-104

34. Balasuriya UB, Leutenegger CM, Topol JB, McCollum WH, Timoney PJ, MacLachlan NJ: Detection of equine arteritis virus by real-time TaqMan reverse transcription-PCR assay. J Virol Methods 2002, 101(1-2):21-28.

35. Willoughby R, Ecker G, McKee S, Riddolls L, Vernaillen C, Dubovi E, Lein D, Mahony JB, Chernesky M, Nagy E, et al: The effects of equine rhinovirus, influenza virus and herpesvirus infection on tracheal clearance rate in horses. Can J Vet Res 1992, 56(2):115-121.

36. Powell DG, Burrows R, Spooner PR, Goodridge D, Thompson GR, Mumford J: A study of infectious respiratory disease among horses in Great Britain, 1971-1976. In 4th International Conference on Equine Infectious Disease: 1978; Princeton. Veterinary Publications; 1978:451-459.

37. Bell SA, Balasuriya UB, Nordhausen RW, MacLachlan NJ: Isolation of equine herpesvirus- 5 from blood mononuclear cells of a gelding. J Vet Diagn Investig 2006, 18(5):472-475.

38. Glaser AL, Renshaw RW, Trock SC, Brady RC, Dubovi EJ: Isolation of Salem virus, a novel equine paramyxovirus, and assessment of its etiologic role in a disease outbreak. Vet Microbiol 2002, 87(3):205-212.

39. Lu Z, Branscum AJ, Shuck KM, Zhang J, Dubovi E, Timoney PJ, Balasuriya UB: Comparison of two real-time reverse transcription polymerase chain reaction assays for the detection of equine arteritis virus nucleic acid in equine semen and tissue culture fluid. J Vet Diagn Investig 2008, 20(2):147-155.

doi:10.1186/1746-6148-8-120

Cite this article as: Lu et al:: Development of one-step TaqMan ${ }^{\circledR}$ realtime reverse transcription-PCR and conventional reverse transcription$P C R$ assays for the detection of equine rhinitis $A$ and $B$ viruses. $B M C$ Veterinary Research 2012 8:120.

\section{Submit your next manuscript to BioMed Central and take full advantage of:}

- Convenient online submission

- Thorough peer review

- No space constraints or color figure charges

- Immediate publication on acceptance

- Inclusion in PubMed, CAS, Scopus and Google Scholar

- Research which is freely available for redistribution 